\title{
Romania's Foreign Trade, Transportation, Credit System and national Riches in Modern Liberal Economic Thinking
}

\author{
Diana-Mihaela Pociovălişteanu ${ }^{1}$
}

\begin{abstract}
:
The main aim of this paper is to analyze the consequences in foreign trade, transportation and the credit system of a nation because of the strengthening of the economic organism, through the economic and political reformation.

The paper refers to the case of the Romanian Economy for the period 1859-1918. Romania's modernization and development are the result of the contribution brought by the thinkers of that time, especially by the radical liberal thinkers.

At the same time, we should not neglect the participation, more modest however, of the conservative thinkers and their contribution in the economic development of the country.
\end{abstract}

Key Words: foreign trade, liberals and conservatives, economic thinking, national riches.

JEL Classification: N13, N14, N23, N24.

\footnotetext{
${ }^{1}$ Professor "Constantin Brâncuşi” University, Faculty of Economics
} 


\section{Introduction}

The monarchy was trying to maintain the equilibrium between liberals and conservatives through their alternation regarding their power in ruling the country. Even so, liberals' weight in the political life was bigger, given their interest to solve some of the problems related to the necessity for the development and the modernization of the country and given their wide-ranging view of epoch's tendencies, covering wider categories of interests.

In the period 1878-1914 the evolution of export and imports expressed as quantity and as value, is:

Table 1: The situation of exports and imports during 1878-1914 (in thousand tons and thousand lei)

\begin{tabular}{|c|c|c|c|c|}
\hline Years & $\begin{array}{ll} & \text { Exports } \\
& \text { Thousan } \\
d s & \\
& \text { Tons }\end{array}$ & $\begin{array}{l}\text { Thousan } \\
\text { ds Lei }\end{array}$ & $\begin{array}{ll} & \text { Imports } \\
& \text { Thousan } \\
\text { ds } & \text { Tons }\end{array}$ & ${ }_{\text {Lei }}^{\text {Thousands }}$ \\
\hline 0 & 1 & 2 & 3 & 4 \\
\hline 1878 & - & 217042 & - & 306582 \\
\hline 1879 & - & 238650 & - & 254482 \\
\hline 1880 & 1324 & 218919 & 311 & 255396 \\
\hline 1881 & 1556 & 206518 & 399 & 274758 \\
\hline 1882 & 1810 & 244730 & 408 & 268852 \\
\hline 1883 & 1603 & 220650 & 593 & 359907 \\
\hline 1884 & 1324 & 184116 & 575 & 294986 \\
\hline 1885 & 1797 & 247968 & 571 & 268539 \\
\hline 1886 & 1705 & 255547 & 572 & 296497 \\
\hline 1887 & 1805 & 265727 & 414 & 304681 \\
\hline 1888 & 1952 & 256789 & 453 & 310378 \\
\hline 1889 & 2237 & 274167 & 485 & 367944 \\
\hline 1890 & 2221 & 275958 & 554 & 262791 \\
\hline 1891 & 2055 & 274663 & 703 & 436683 \\
\hline 1892 & 1959 & 285384 & 653 & 380747 \\
\hline 1893 & 2895 & 370652 & 727 & 430490 \\
\hline 1894 & 2071 & 294198 & 718 & 422142 \\
\hline 1895 & 2041 & 265048 & 617 & 304575 \\
\hline 1896 & 2660 & 324057 & 656 & 337923 \\
\hline 1897 & 2082 & 224180 & 631 & 355783 \\
\hline 1898 & 2644 & 283182 & 883 & 389908 \\
\hline 1899 & 1301 & 149120 & 790 & 333268 \\
\hline 1900 & 2047 & 280000 & 412 & 216986 \\
\hline 1901 & 2985 & 353831 & 484 & 292436 \\
\hline 1902 & 3318 & 374819 & 462 & 283345 \\
\hline
\end{tabular}




\begin{tabular}{|c|c|c|c|c|}
\hline$\overline{1903}$ & 3238 & 355630 & 4470 & 269924 \\
\hline 1904 & 2269 & 261872 & 525 & 311372 \\
\hline 1905 & 3464 & 457101 & 731 & 337538 \\
\hline 1906 & 4213 & 491360 & 734 & 422114 \\
\hline 1907 & 4200 & 554019 & 935 & 430509 \\
\hline 1908 & 2823 & 379431 & 871 & 414058 \\
\hline 1909 & 3297 & 465057 & 716 & 368300 \\
\hline 1910 & 4489 & 616505 & 772 & 409716 \\
\hline 1911 & 5390 & 691720 & 986 & 569745 \\
\hline 1912 & 4327 & 642104 & 1214 & 637906 \\
\hline 1913 & 4569 & 670705 & 1374 & 590013 \\
\hline 1914 & 3127 & 451891 & 1145 & 504241 \\
\hline
\end{tabular}

Source: The Romanian Encyclopedia, Vol. IV (National Economy), ASPER, 1940, 464-465

From the data presented, one can notice that both imports and exports had great fluctuations during 1878-1914. For example, in 1887 exports were 265.727 thousands lei, and imports 304.681 thousands lei, a real fact that determined a deficit totaling 38.954 thousands lei; however, in 1896 exports increased at 324.057 thousands lei, imports at 337.923 thousands lei, while the registered surplus being 13.866 thousand lei, quite a better position than in 1887 .

However for almost the whole period and towards the end of the nineteenth century, Romania's balance of trade had deficits showing that Romania was an exporting country, especially of raw agricultural materials and an importing country of foreign industrial products. Again, the causes are the negative effects of the convention with Austro-Hungary, the strong agrarian crises that affected the whole world at the end of the nineteenth century, the price difference between the products exported and the imported ones, and the poor crops obtained due to the climatic conditions.

\section{Data Analysis}

Between 1900 and 1914, both exports and imports increased and the balance of trade was positive (for example in 1900 the balance of trade surplus was of 63.014 lei; in 1907 the surplus was 123.510 lei; in 1911 export overrunning the imports with 4.404 lei). In 1904 and 1908 the trade balance was negative because of the draught that affected the agriculture in the agricultural year 1903-1904 and because of the consequences of the 1907 peasants' revolts. A positive balance of trade for most of the years after that was occurred, showing an efficient Romanian foreign trade, however one can not justify the conclusion that the country would have had a positive balance of payments too. The explanation is that during 1901-1914 Romania had contracted foreign debts which it had to return, and on the other hand, the foreign capital which permeated Romania's economy was taking over the border remarkable profits which were hanging up heavily in the passive of the balance of payments. 
The highest value of exports was reached in 1911 and of imports in 1912. This fact demonstrates, on the one hand the integration of the Romanian market in the international market circuit, and on the other hand the great dependence of the economy on foreign trade.

During 1901-1913 it is noticed a doubling of the total value of the foreign trade.

As per capita foreign trade Romania occupied the eighth place in the world after Argentina, Holland, Belgium, England, France, Germany and the United States in 1913. Romania's structure of foreign trade (imports-exports) during 1913-15 is presented below in Table 2:

Table 2: The geographic orientation of Romania's foreign trade during 1913-15 (in thousands lei and \% of the total-imports-exports)

\begin{tabular}{|c|c|c|c|c|c|c|}
\hline & 1913 & & 191914 & & 1915 & \\
\hline Countries & $\begin{array}{l}\text { Thousands } \\
\text { lei }\end{array}$ & $\%$ & $\begin{array}{l}\text { Thousands } \\
\text { lei }\end{array}$ & $\%$ & $\begin{array}{l}\text { Thousands } \\
\text { lei }\end{array}$ & $\%$ \\
\hline $\begin{array}{l}\text { Total, out } \\
\text { of which: }\end{array}$ & 1260718 & 100,0 & 956131 & 100,0 & 903124 & 100 \\
\hline $\begin{array}{l}\text { Austro- } \\
\text { Hungary }\end{array}$ & 234050 & 18,56 & 267334 & 27,46 & 432361 & $\begin{array}{l}47,8 \\
7\end{array}$ \\
\hline Germany & 290227 & 23,03 & 230195 & 24,08 & 265499 & $\begin{array}{l}29,4 \\
0\end{array}$ \\
\hline Bulgary & 11160 & 0,89 & 13134 & 1,37 & 39078 & 4,32 \\
\hline Russia & 16555 & 1,31 & 14404 & 1,51 & 31278 & 3,46 \\
\hline Turkey & 52109 & 4,13 & 32918 & 3,45 & 25039 & 2,77 \\
\hline $\begin{array}{l}\text { United } \\
\text { Kindom }\end{array}$ & 100578 & 7,98 & 91633 & 9,58 & 21281 & 2,35 \\
\hline Italy & 93194 & 7,39 & 58104 & 6,08 & 19997 & 2,21 \\
\hline France & 97662 & 7,75 & 54579 & 5,71 & 16507 & 1,83 \\
\hline $\begin{array}{l}\text { Switzerlan } \\
\text { d }\end{array}$ & 8118 & 0,64 & 9378 & 0,98 & 15542 & 1,72 \\
\hline Greece & 8410 & 0,66 & 8528 & 0,89 & 8845 & 0,98 \\
\hline Serbia & 3017 & 0,23 & 3499 & 0,37 & 8304 & 0,92 \\
\hline Holland & 50174 & 3,98 & 32895 & 3,44 & 4378 & 0,48 \\
\hline $\begin{array}{l}\text { United } \\
\text { States }\end{array}$ & 30046 & 2,55 & 16730 & 1,75 & 1172 & 0,13 \\
\hline Belgia & 198521 & 15,75 & 73912 & 7,73 & 1139 & 0,12 \\
\hline $\begin{array}{l}\text { Other } \\
\text { countries }\end{array}$ & $\ldots$ & 5,15 & $\cdots$ & 5,60 & $\ldots$ & 1,44 \\
\hline
\end{tabular}

Source: Sută, N. (coordinator), The history of foreign trade and of Romanian trade policy, Economical Publishing House, Bucharest, 1998, p. 123.

In 1913 Germany was the biggest commercial trader with Romania, while in 1914 and 1915 this place was occupied by Austro-Hungary. In 1914 and 1915 Belgium, England, France and Italy recorded an important waning of foreign trade with 
Romania due to the interruption of the naval transports, because of the closing of Boxford and Dardanelle straits. Even if it was under foreign domination, Transylvania kept contact with Romanian economy and Moldavia, the trade with those provinces developed surprisingly, especially after Romania signed the Trade Convention with Austro-Hungary in 1875. The transports and the telecommunication services, tightly connected to the internal traffic of goods, have also developed and constantly diversified. The achievements in this domain were the result of large budget funding to build roads, railways and bridges.

An ascendant evolution knew as "the asphalted roads" connected with the road network in Transylvania, Banat, Bucovina and Bessarabia, from $775 \mathrm{~km}$ in 1863 to $7800 \mathrm{~km}$ in 1887 and $29800 \mathrm{~km}$ in 1916 . Romania had a road network of $46000 \mathrm{~km}$, out of which over $5000 \mathrm{~km}$ national roads, approximately $5000 \mathrm{~km}$ county roads, and $36000 \mathrm{~km}$ dirt roads.

In the area of railway connection, during 1869-1915 there were built $2554 \mathrm{~km}$ of simple railway route, with 404 stations and 39 flag stations, 1497 of railway carriers and 25736 freight railway carriers. Naval and maritime transportation experienced significant progresses. In 1905, Romanian maritime fleet was composed of nine big ships, with $30000 \mathrm{CP}$, out of which five ships cover Braila-Rotterdam, and four were used for people and cargo transportation between Constanta and Constantinopol, a route which got recently extended to Smirna and Alexandria.

At the same period, 1905, Constanţa was considered to be the fourth sea port in Europe, with a quite well shipment loading and unloading system, barrages, storage and warehouses for trade, grain elevators and dryers for cereals, etc. Satisfactory results were also obtained in the field of telecommunications. The telegraph and telephone were used in Romania a few years after their invention. For the telegraph, we should note that connection routes' length increase from $3420 \mathrm{~km}$ in 1873 to $3954 \mathrm{~km}$ in 1877, $5798 \mathrm{~km}$ in 1891 and $9062 \mathrm{~km}$ in 1913. It has been noticed a growth of 2,64 times between 1873 and 1913. With respect to telephone during 1894-1913, the number of telephone offices has grown from 3 to 1108, the telephone call boxes from 10 to 3304, and that of branch extensions from 177 to 17979 .

Romanian transportation and telecommunications have stimulated the development of Romanian economy, strengthening its modern character. In this sense, an important measure that has been taken by the liberal government was to redeem the railway roads and get them managed by the Romanian state.

At the end of the nineteenth century, the banking and the credit system was already set up, being supported by the state, which participated with capital or by guarantying the financial operations. Through the banking and the credit system, there have been created conditions for insuring and guarantying of investments in all fields of activity. The National Bank, founded in 1880, was a strong state financial instrument existing in the hands of liberals for developing the industry and the trade. 
The structure of the banking and the credit system at the beginning of the twentieth century is presented bellow in Figure 1:

Figure 1. The structure of the banking and the credit system
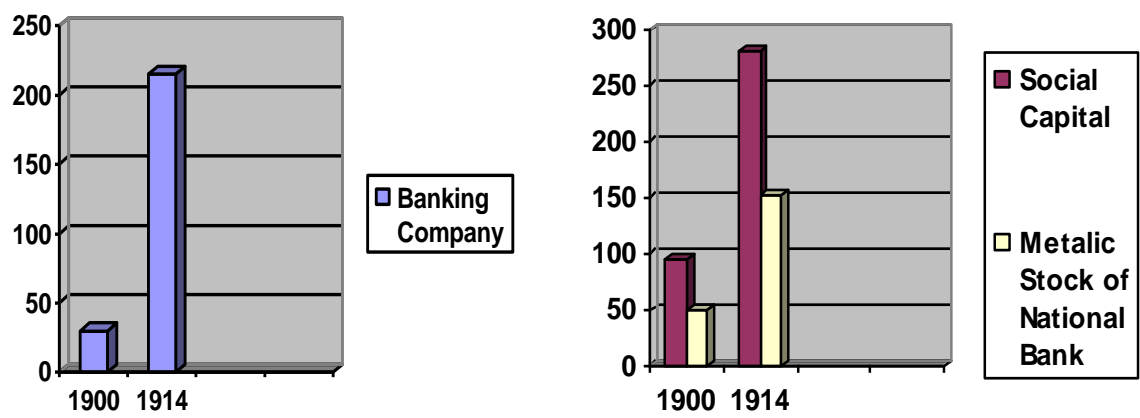

Source: Romanian Academy, Romanian History (coordinator Berindei, D.), The Encyclopedic House Publishing, Vol. VII, Tom II, Bucharest, 2003, p. 124.

We notice that the number of banking societies has grown from 1900 to 1914 by 7 , 16 times (from 30 to 215), the social capital funds has increased almost 3 times (from 94,2 mil to 281, 5 mil lei), and the metallic stock of the National Bank of Romania has increased 3 times (from 49,2 mil lei to 153 mil lei). These data proves once more, how the banking and the credit system has evaluated in the direction of modernizing and of obtaining beneficial results for country's economy.

In Transylvania, we also assist to the transformation of the old credit system that relied on usury, into a modern banking system, under the control of the Austrian and Austro-Hungarian capital. At the end of the nineteenth century, the Magyar Banks owned over half of the total banking capitals, the Saxon ones owned 25-35\% and the Romanian ones $15-20 \%$. Although the percent of the Romanian banking capital was small compared with the others, the Romanians from Transylvania made efforts to set up their own banking network, from four credit institutions in 1879, to 97 in 1900 .

The results obtained in the banking and the credit system spurred in a considerable measure economy's development and modernization and the behavior of economic agents, these data being confirmed by the opinions of the liberals of that time. In the fiscal field, the results obtained demonstrate that the state budget has increased ceaselessly, which got to the diversification of the Romanian economic life. Graphically, the evolution of incomes and budgetary expenses is presented below in Figure 2. 
Figure 2: The evolution of incomes and budgetary expenses

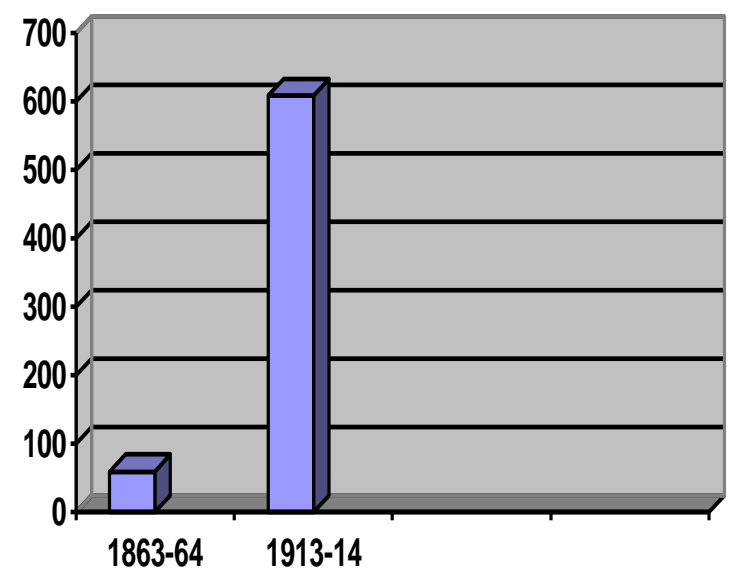

\section{Incomes \\ DExpenses}

Source: Mureşan Maria, Mureşan D., The history of economy, Economical Publishing House, Bucharest, 1998, pp.166.

It has been noticed that the revenues have increased from 60,1 million lei in $1863 / 1864$ to 608,5 million in $1913 / 1914$, and the expenses from 62,3 million lei to 512,2 million lei during the same period. The statistical data presented by $\mathrm{V}$. Axenciuc, (1992-2000) regarding the evolution of the budget from 1878 to 1914, show that until 1900, a period of 37 years, surpluses were present in 24 years.

This demonstrates once again that the promoted fiscal policy, in different measures by different governs, liberal or conservative, was contributing to the fulfillment of a necessary understructure for the modernization of the country, bringing his contribution to the realization of the economy in concordance with the exigencies of the international economy. From an economic point of view, in 1914, Romania was completely different from Romania in 1866. We can demonstrate this statement taking into consideration the evolution of all economy's sectors, the connections established between them, the national riches, the accumulated material goods made by the human activity and the natural goods capitalized as presented in Table 3:

Table 3: The evolution of national riches in 1860-1914 (million lei)

\begin{tabular}{|c|c|c|c|c|c|}
\hline \multicolumn{6}{|l|}{ Years } \\
\hline Sectors & $1860-64$ & $1880-84$ & $1900-4$ & $1912-14$ & $\begin{array}{l}1912-14 / \\
1860-64\end{array}$ \\
\hline $\begin{array}{l}\text { Agriculture, forestry, } \\
\text { the stock of food and } \\
\text { seed }\end{array}$ & 1848,0 & 3681,9 & 6585,0 & 1052209 & $569 \%$ \\
\hline $\begin{array}{l}\text { The buildings, the } \\
\text { houses and lasting } \\
\text { goods of consumption }\end{array}$ & 235,4 & 388,6 & 1471,9 & 2386,8 & $1014 \%$ \\
\hline
\end{tabular}




\begin{tabular}{|c|c|c|c|c|c|}
\hline $\begin{array}{l}\text { The transports and } \\
\text { communications }\end{array}$ & 20,6 & 525,2 & 1417,0 & 2543,4 & $12347 \%$ \\
\hline Industry & 60,9 & 68,9 & 415,2 & 1171,2 & $1923 \%$ \\
\hline Commerce & 192,0 & 582,4 & 659,8 & 1075,3 & $560 \%$ \\
\hline $\begin{array}{l}\text { The public utility } \\
\text { sphere }\end{array}$ & - & - & - & 250,4 & - \\
\hline $\begin{array}{l}\text { The stock of metal } \\
\text { account, }\end{array}$ & 37,0 & 85,3 & 177,0 & 381,0 & $1030 \%$ \\
\hline Active gross & 2393,9 & 5332,3 & 10725,9 & 18331,0 & $766 \%$ \\
\hline $\begin{array}{l}\text { External } \\
\text { duties }\end{array}$ & 50,1 & 547,0 & 1577,3 & 3065,6 & $6119 \%$ \\
\hline Active net & 2343,8 & 4785,3 & 9148,6 & 15265,4 & $651 \%$ \\
\hline
\end{tabular}

Source: Axenciuc, V., The national riches of Romania. Comparative historical researches, 1860-1939, Bucharest, 2000, pp.12, 15.

Comparing this data, we notice remarkable increases in the field of transportation and communications $12347 \%$, in industry $1923 \%$ and in the stock of account metal $1030 \%$. This evolution describes clearly the alert rhythm of modernizing the national economy. The weight of different spheres in the national riches is presented below in Table 4:

Table 4: The development of the national riches during 1860-1914 (\%)

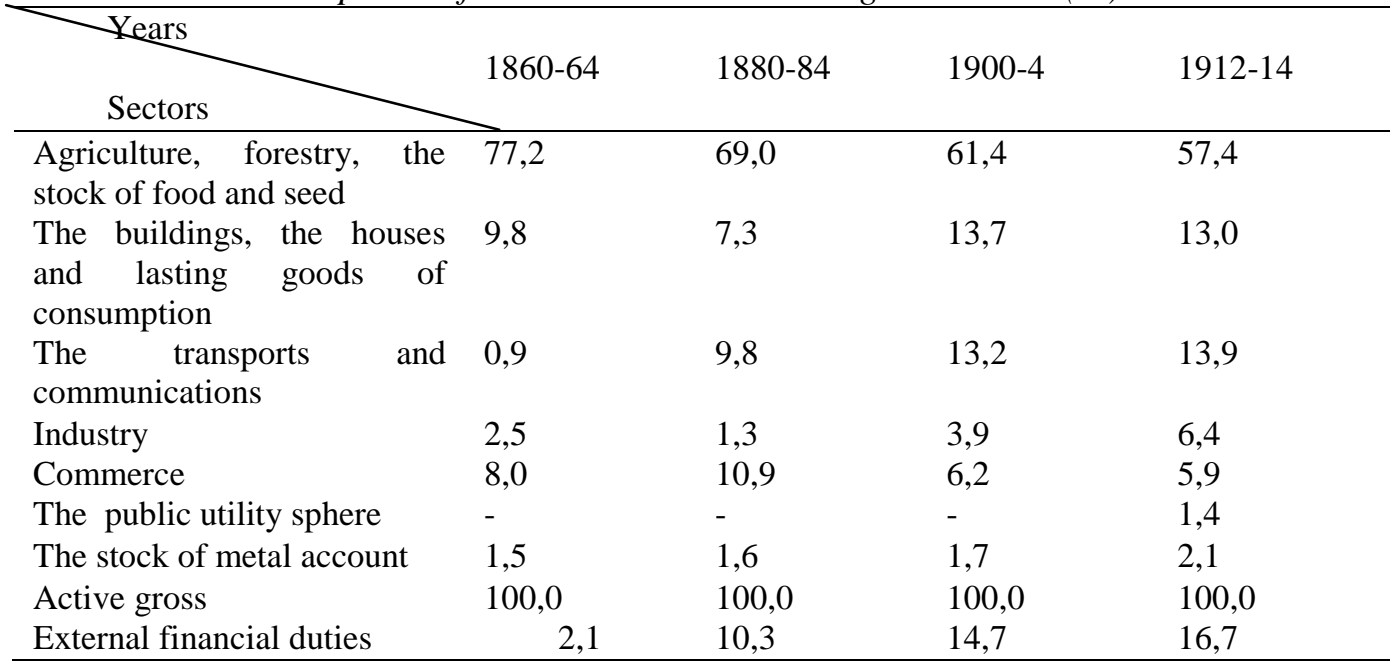

Source: Axenciuc, V., The national riches of Romania. Comparative historical researches, 1860-1939, Bucharest, 2000, pp.161.

After 50 years, the weight of the agrarian field has decreased almost by $20 \%$ that is also found in other spheres as well especially in transportation and industry. The foreign debt has increased by 8 times, suggesting that there were investments made with preponderance in transportation, industry, the municipal sector and probably in consumption. 


\section{Conclusion}

During the period under study the positive results obtained in all spheres of the Romanian economy has affected the country positively and has reduced the country's difference from other Western countries. The development and the modernization of the Romanian society as well as the Romanian economy at the end of the nineteenth century and the beginning of the twentieth century, is due to the political elite, especially the liberal one, without underestimating the significant role of the conservative political elite as well.

Although the opinions of liberals and conservatives differed in many ways the methods an especially the modernization rhythm, "the contribution regarding the public institutions' participation in the process of infrastructure and public edifices building is sensible equal"2. The liberal ideas, especially the radical ones, had a remarkable impact on the economic life in Romania in the modern period, contributing to the country's integration in the world economy.

\section{References}

Aurelian, P.S., (1967), Economical Works, The Academy Publishing House, Bucharest, Romania.

Axenciuc, V., (1992), The Economic Evolution of Romania, Statistical - historical Researches, 1859-1947, The Industry, Bucharest, Romania.

Axenciuc, V., (1992), The Economic Evolution of Romania, Statistical-historical Researches, 1859-1947, Vol. I, Bucharest, Romania.

Axenciuc, V., (1996), The Economic Evolution of Romania, Statistical - historical Researches, 1859-1947, The Agriculture, Bucharest, Romania.

Axenciuc, V., (1997), Introduction in the Economic History of Romania: The Modern Age, Bucharest, Romania.

Axenciuc, V., (1999), Introduction in the Economic History of Romania, Bucharest, Romania.

Axenciuc, V., (2000), The National Riches of Romania, Comparative Historical researches. 1860-1939, Bucharest, Romania.

Colescu, L., (1907), Economic Progress in Romania - M.S. King Carol I (1866-1906), Bucharest, Romania.

Constantinescu N. N., (coord.), (1997), The Economic History of Romania, Vol. I, Economic Publishing House, Bucharest, Romania.

Mureşan Maria, Mureşan D., (1998), The History of Economy, Economical Publishing House, Bucharest, Romania.

Pociovalisteanu, Diana-Mihaela, (2006), Contribution of the Liberal Economical Thinking to the Industrial Development of Romania (1859-1918), European Research Studies, Vol. IX, issue (3-4) 91-99.

Pociovalisteanu, Diana-Mihaela, Thalassinos, I.E., (2008), The Regional Development of Romania as a New Member of the European Union, International Conference,

\footnotetext{
${ }^{2}$ The Romanian Academy, 2003, The History of Romanians (coordinator Berindei, D.), The Encyclopedic House Publishing, Vol., VII, Tom II, Bucharest, pp. 51.
} 
Eastern Economic Association, Boston, MA, USA.

Rociovalisteanu, M-D., Thalassinos, I.E. (2008). The beginning and some national particularities of liberalism. Metalurgia International, 13(2), Special Issue, 172-177.

Sută, N. (coordinator), (1998), The History of Foreign Trade and the Romanian Trade Policy, Economical Publishing House, Bucharest, Romania.

The Encyclopedia of Romania, (1939), Vol. III, The National Printing Works, Romania.

The Romanian Academy, (2003), The History of Romanians (coordinator Berindei, D.), The Encyclopedic House Publishing, Vol. VII, Tom II, Bucharest, Romania.

The Romanian Encyclopedia, (1940), Vol. IV (National Economy), ASPER, Bucharest, Romania. 